\title{
Problems and Future Possibilities of Visegrad Cooperation
}

\author{
SZILÁGYI Ilona Mária ${ }^{1}$
}

"...this regional cooperation is encouraging the hope that it can influence the present and near future of Central Europe in the framework of the European Union. It was the first time for centuries that instead of conquered and defeated state, the participation status and possi- bility is given to this region. Now it also depends on us what is our present and what will be our near future." [1:42]

\begin{abstract}
The Visegrad Cooperation was founded in 1991 by the newly independent three countries: Czechoslovakia (as it was called then, now Czech Republic and Slovak Republic), Hungary, and Poland. The spirit of the $14^{\text {th }}$ century arose. Their aim was to promote joining Western integrations by mutual assistance. They had to face several problems during times which obstructed the cooperation for longer or shorter periods, but it has survived and it was able to find new goals for itself. Its $20^{\text {th }}$ "birthday" was celebrated in 2011, and nowadays the role of regional integra- tion is larger than ever before. At present there are still interfering factors which cause problems, so I shall examine them in my study and I shall outline the future possibilities of Visegrad Cooperation.
\end{abstract}

\section{Introduction}

The history and the results of Visegrad Cooperation are quite big issues that I am not going to discuss in this study, as I have already published regarding these questions. I have also pre- viously introduced the participating four countries (Czech Republic, Hungary, Poland, and Slovakia) in an essay. So I am going to highlight three milestones of the history of Visegrad Cooperation.

The first milestone was the Royal Meeting of Visegrad in 1335, attended by king Charles Robert of Hungary, Czech king, John of Luxemburg, and Casimir III of Poland. In addtion to further goals there was the plan for successful Central-European Cooperation, which was forgotten for years, remaining without any results. [2][11]

The second milestone was more than 650 years later. The Visegrad Cooperation was re- vived in 1991 when the main aim was coordinated Western integration.

The third one was in 2004 when the V4 joined the European Union, which brought it to a crossroads: the objectives had been fulfilled and thus the partnership ended or new goals would be needed to revive the organization. The last prediction was realised partly: regional cooperation, consultation, joint actions in the framework of EU and other international or- ganizations.

\footnotetext{
1 National University of Public Service, The Faculty of Military Sciences and Officer Training, Doctoral School of Military Sciences, Ph.D. student, ilonamaria@freemail.hu
} 
20 years has flown by in the life of Visegrad Cooperation, it has become an adult but it has not reached its final form. Lots of problems, inhibitors, and obstacles are here, which I am going to present first.

In the second part of my essay I will try to deal with the problems mentioned above and I shall outline the future possibilities of the V4.

\section{The Problems of Visegrad Cooperation}

There were many efforts to create regional cooperation in Central Europe in the $20^{\text {th }}$ centu- ry but these were rather unsuccessful. Although at the end of this century there were some more positive initiatives like the CEI (Central European Initiative) ${ }^{2}$ and CEFTA (Central European Free Trade Area) ${ }^{3}$. [3] In this area the cooperation is in initiatory phase because of disadvantageous economic, historical, political, and ethnic conditions. [4] Effective and good cooperation is unknown and it is being learnt, formed at present with more or less success. Thus the lack of the tradition of successful cooperation can be the most improtant problem.

The Visegrad Cooperation faces external and internal tensions as not all Central European countries are member states of it. The option of enlargement includes the ability of a strong core which attracts the other Central European states as a positive example. For this it must provide stability in the region which also depends on a successful and deep relationship with- in Visegrad Cooperation. [1]

Many criticize this cooperation, stating that it is not efficient, but this means impatience because they misunderstood and made incorrect conclusions many times. So “...we have to consider that it works as a not obligatory interest conciliation forum, a platform of opinions, attitudes, beliefs and interests presentation and consultation forum from its birth." [1: 46] The mechanism of cooperation was laid down in 1999 [8] and 2004 [10]. The organization was founded in 1991, and does not bind the V4 to take a common view of issues, at least at the expense of their own interest. [5]

Historical injuries are determining for the life of a state, they influence its international connections. The states of the Visegrad Cooperation are neighbours and during their history grievances developed against each other. These grievances must learn to be managed, taking steps forward, and rising above them. [6] Sometimes the option of reviving old allainces has arisen, but these are rather fears than real possibilities, for example the extreme nationalists think that former Czechoslovakia can be restored when the Czech Republic and Slovakia work closely with each other.

The actual borders of the region were made in the $20^{\text {th }}$ century and they were changed many times during history. [7] There were numerous border disputes again and again that caused mixed ethnic habitants in border areas. The authorities tried to solve this problem by inhabitant exchange, violent colonization, and language laws. But the rules bringing peace and quiet for everyone have not yet been born, and in my opinion you can not create justice in this question, there is no perfect solution, only a mutually acceptable, tolerable situation

2 It was founded in November 1989, foundation members: Hungary, Italy, Jugoslavia and Austria. It has been extended to 15 members during the following years. www.cei.int(downloaded: 1010 2012)

3 It was founded in 1992 by the Visegrad countries, then other countries joined it. Its importance was temporary because the Central European members exited automatically after they joined the EU, and nowadays it is a Western Balkan organization. www.ecopedia.hu/cefta (downloaded: 10102012 ) 
which needs empathy, patience and mutual esteem. Decreasing the role of state borders and thinking as one region can minimalize extreme and hateful views.

The deepening, strengthening, and enrichment of the relations inside the V4 is very im- portant so it has to be pursued. This has to be seen as the most important task and after it is reached the Eastern Partnership ${ }^{4}$ of the EU or the West Balkan could move forward.

Pursuit of dominance stems from the existence of the nature of states and lots of examples can be found during the decades of Visegrad cooperation. For example between 1990-1998 the Slovak strategic position was overestimated by the current government (Vladimir Me- ciar) or we can mention the Poles' ambitions for a leading role in the region, which arises at times. But if this cooperation wants to be effective, mutual partnership has to be reached. [8] Although only Slovakia (from among the 4 countries) is a member of the euro zone, they opposed the grant rescue package for troubled states. The Visegrad Identity is still missing because lots of times the single interest of member states are emphasized at the expense of the others.

The size and weight of the 4 Visegrad countries is different, and Poland has emerged because it is bigger than the other 3 countries together. So it is not surprising that Poland is supposed to be the leader of the region by some people, but it would rather be among the great powers of Europe. Germany and France are getting closer to Poland and one reason for it is that they are afraid of a strong regional organization. It is remarkable that in the Council of the EU the votes of the V4 together are almost equal to the votes of Germany and France together. Perhaps not surprisingly Germany is happy to take part in the Visegrad meetings as an observer. [9]

There are only bilateral intergovernmental relations in Central Europe and unfortunately these are often formal. Thus the infrastructural connection of the region has not happened yet, which hampers economic cooperation. The transition to a market economy was a common problem for the V4 at the begining of the $21^{\text {st }}$ century and enforced certain sectors to make structural changes. The developmental differences create difficulties in the cooperation of neighbours even today, so developmental policy gets high priority. [10]

The members of the V4 are similar economically therefore they compete with each other rather than being partners or complementing each other's economies. Their geographical features are also similar and they struggle with the same problems. The development of infra- structure, their consumption structure, and the ability of capital attraction is similar, too. $[11:$

46-47] There were significant economic declines in the Visegrad countries after the change of regime, and they have not yet been solved. [11: 50] The stable, strong economy definitely strengthens the cooperation among the allies. The commercial stability of the region is in- hibited by the Slovak Euro, the high inflation in Hungary. All four countries are reliant on foreign capital and investment, which also makes it difficult to cooperate with each other in this area, and even rivalry has developed in the competition for foreign capital. [3] The level of intra-regional trade is low, the predictable foreign trade regime is missing, and the incentive for trade is poor with each other. Only the trade between the Czechs and Slovaks is lively (but it is because of the former unity, unfortunately, and not the relationships within

4 This program was started in 2009; its aim is closer political cooperation and facilitates an economic process among the former Soviet Union members (Armenia, Azerbaijan, Belarus, Georgia, Moldova, and Ukrain). www.ec.europa.eu/dgs/home-affairs/what-we-do/policies/internationalaffairs/eastern-partnership/index_en.htm (downloaded: 0109 2013) 
the region). $90 \%$ of services "use" these four countries as a transit country. The Visegrad countries also maintain relations with other states, and these are stronger than those between each other, e.g. Czech-German/Austrian; PolishBaltic States; Hungarian-Austrian/Slove- nian/Croatian/Ukrainian cooperation. [4]

\section{The Aims of the Visegrad Cooperation}

The "New Visegrad Declaration" was accepted in 2004 in Kroměřǐz [12] and is another milestone in the history of the cooperation. Four areas of cooperation were assigned and the mechanism of the cooperation was also recorded.

Areas of cooperation:

- cooperation within the V4 area;

- cooperation within the EU;

- cooperation with other partners;

- cooperation within NATO and other international organisations. Mechanism of cooperation:

- governmental cooperation;

- meetings of presidents of the V4;

- cooperation of parliaments of the V4 countries.

First I shall describe the four areas of cooperation. The first area is the cooperation within the V4 area including culture, education, youth exchange, science, infrastructure, and envi- ronment. There is the continuation of the strengthening of the civic dimension of the Viseg- rad cooperation within the International Visegrad Fund and its structures, cross-border and Schengen cooperation. In addition to the exchange of experience on foreign development assistance policy, and views on possible cooperation in the field of labour and social policy. New areas like the fight against terrorism, organised crime and illegal migration, disaster management, and defence and arms industries.

The second area is cooperation within the EU meaning active contributions to the devel- opment of the CFSP, including the "Wider Europe — New Neighbourhood" policy and the EU strategy towards the Western Balkans, and also active participation in the development of the ESDP, as a contribution to the strengthening of relations between the EU and NATO and deepening of substantive dialogue between both organisations. Consultations, co-operation on current issues of common interest, as well as exchange of experience in the area of Justice and Home Affairs, Schengen cooperation, including protection and management of the EU external borders, visa policy. Creating new possibilities and forms of economic co-operation within the European Economic Area, and consultations on national preparations for joining the EMU (European Monetary Union) ${ }^{5}$.

The third area is cooperation with other partners that have an interests in Central European countries. Cooperation with other regional structures, and with EU and NATO candidates and aspiring countries in support of reforms essential for their European and Euro-Atlantic perspec- tive and collaboration in effective implementation of programmes of cooperation of these coun- tries with the EU and NATO. Collaboration with other interested countries and organisations.

5 The agreement among the participating member states of the European Union is to adopt a single hard currency and monetary system www.ebook.law.uiowa.edu/ebook/faqs/what-is-the-european-monetary-union (downloaded: 0704 2014) 
The fourth area is cooperation within NATO and other international organisations which are the following: the cooperation and consultations in the framework of NATO and in its defence capabilities; strengthening of transatlantic solidarity and cohesion; and cooperation on the basis of the V4 experience to promote a common understanding of security among the countries as- piring to European and Euroatlantic institutions. Enhanced cooperation within the international community in the fields of new security challenges, with a special emphasis on combating in- ternational terrorism. Cooperation and consultation in the OSCE on issues of common concern for V4 countries, as well as exchange of information in international organisations (UN, Coun- cil of Europe, OECD, etc.) are very important, as are considerations of possible joint initiatives. Possible mutual support of candidacies in international organisations and bodies.

Secondly I present the mechanisms of cooperation: governmental cooperation, meetings of Presidents of the V4, and cooperation of Parliaments of V4 countries. Governmental co- operation contains a rotating one-year presidency, each chairmanship prepares its own pres- idency programme ensuring, among others, continuity of long-term V4 cooperation. There is one official Prime Ministerial summit a year at the end of each presidency, and occasion- al informal meetings of Prime Ministers and Foreign Ministers before international events. Deputy foreign ministerial meetings precede the PM official summits and meetings of other ministers in V4 and V4+ format. Intensified communication of V4 national coordinators and their key role in internal and inter-state coordination is included. Last but not least consultation and cooperation of Permanent Representations to the EU and NATO in Brussels, as well as in all relevant organisations (OSCE, UN, CoE, OECD, WTO, etc.) are very important as well as the International Visegrad Fund ${ }^{6}$ and its structures. [10]

\section{The Future Possibilities of Visegrad Cooperation}

In 2011 the Visegrad cooperation celebrated its $20^{\text {th }}$ anniversary with the "Bratislava Declara- tion". In the first part of it the results made to date are described and later the future purposes of the V4 are declared. V4 confirm their determination to continue and further develop mu- tual cooperation aimed at contributing towards a strong, stable and democratic Europe and strengthening its position in the global arena in the interest of peace and sustainable devel- opment. They take part actively in the strengthening of Europe by carry out projects which enhance the competitiveness and foster cohesion of the V4 and EU at a global level to solve the economic and financial crises. Energy security is very important for the V4 so the internal energy market is going to be extended and deepened as a regional organisation within the framework of the EU. Routes, sources, diversification of energy suppliers are needed for this, and energy infrastructure, especially implementation of the North-South gas interconnec- tions need to be improved, as well as an oil and electricity network needing to be modernized.

Road, rail, and river transportation infrastructure needs to be improved in a short time for cross border cooperation and cooperation among citizens.

Deeper cooperation must be built within the framework of the EU, especially in the field of common foreign and security policy, to make visible the V4 for other partners. Stability and democracy is fostered in the neighbourhood of the EU, and the Eastern Partnership Program

6 The International Visegrad Fund is an international organization based in Bratislava founded by the governments of the V4 in Štiřín, Czech Republic, on June 9, 2000. www.visegradfund.org/about/ (downloaded: 0704 2014) 
supports the West Balkans in their integration to the EU and NATO. The V4 fosters devel- opment of Euro-Atlantic relations, including NATO-EU strategic supplement, which is key to the long-term security of Visegrad cooperation and the whole of the Euro-Atlantic area.

In the current international environment there are continuously growing complex chal- lenges which cannot be answered by any single country alone, therefore the V4 actively con- tributes to the war against terrorism, human and drug trafficking, illegal migration, as well as other security threats including cyber threats.

The Visegrad cooperation has become a well-based brand and an appreciated partner. It is going to be opened for cooperation along the lines of common interest with other countries and regional organisations in the framework of V4+. This organisation is led by solidarity and a theory of cooperation, so it is going to continue its important regional role. [7]

The possible areas of cooperation of the V4 can be the following: military, energy secu- rity, Eastern-Partnership Program, and cohesion support within the EU. The maintenance of the level of the cohesion support is quite important for every country. The reform of Common Agricultural Policy creates a good opportunity for common activities.

Energy security has come to the for in recent years which means the risk of the depen- dence on Russian energy supply for all the four countries. This dependence should be re- duced effectively with the creation of a North-South energy corridor. [3] An energy strategy should be developed that ensures energy supply for at least one year in case of any crisis, and the diversification of energy routes is necessary. Energy consumption is increasing with the development of the economy and the growth of population. Renewable energy sources' effi- cient usage is necessary because according to a survey until 2030 energy consumption will grow 50\%. More than half of the energy resources are made up of oil, gas, and coal. Between

2000 and 2015 the gas need will increase $100 \%$ and the oil need will grow 25\%. [6: 21-22]

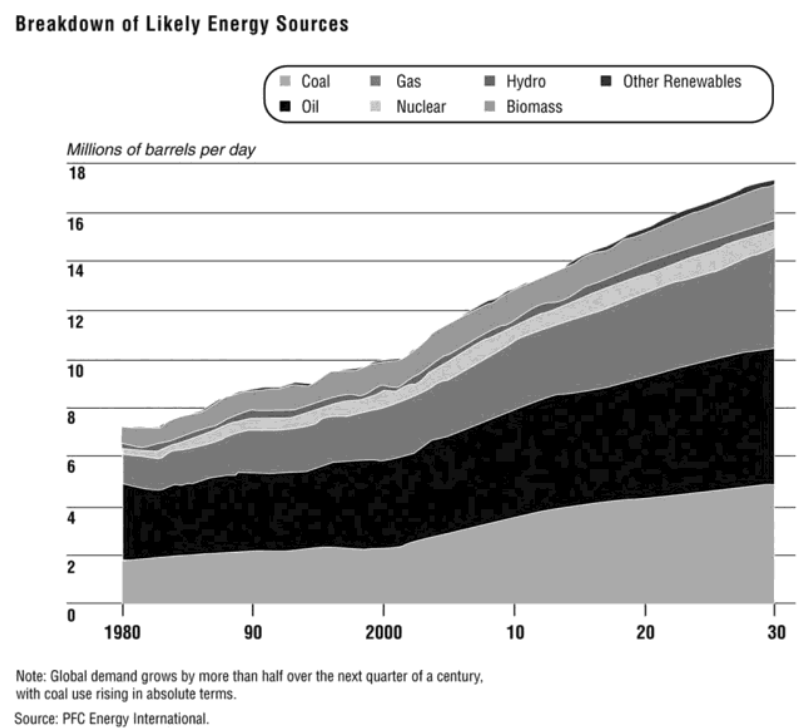

Figure 1. Global Trends 2025: A Transformed word ${ }^{7}$

7 www.dni.gov/nic/PDF_2025/2025_Global_Trends_Final_Report.pdf p43 (downloaded: 0304 2014) 
The V4 has successfully collaborated in advancing Western Balkan countries as they also contributed to Albania and Croatia joining NATO, so this line of action should also be continued in the future. The efforts of Montenegro, Bosnia-Herzegovina, Serbia should be supported consistently. [6: 19]

A single position should be advocated in the Eastern Partnership program that could raise the prestige of the organisation. Pushing east the borders of the EU would be very important from security policy view, and it could open a market for investments. We must not forget that these countries have influence on the economy of Europe, and thereby energy security, too. [3] The V4 has already had an effective role in the dialogue with third countries so it cannot be stopped in the future. Visegrad countries have been in contact with Japan, Israel, and the Benelux Union within the framework of V4+. Their experience in security policy has been handed over to other Central European countries since 2009.

The International Visegrad Fund is there to strengthen cooperation between the civilian dimension through scholarship programs, student exchange programs, annual student confer- ences, and it gives an opportunity to young researchers to exchange ideas. [6: 19-20]

The V4 has to know and discover the other states of the region and this process demands money, time, education, effort, and learning. Successful cooperation is the key to deliberate policy and social intents. Patience and perseverance are needed, Visegrad Cooperation has to move along in small steps, slowly because it is worth it in the long term and it needs constant maintenance and care by its members.

One of the possible roles of the V4 is to organize the Central European countries along the lines of the Benelux Union and Nordic Council ${ }^{8}$, in order to support political cooperation in the region. The Visegrad Cooperation is in a favourable position from the view of regional cooperation because the EU strongly supports this format. And it is not only a framework but also provides protection in the EU implementation of regional cooperation. Therefore the Visegrad Four countries could accomplish regional tasks within the EU, take part actively in shaping local and foreign policy, in addtin to strengthening and deepening their mutual rela- tions in the future. Such important areas like transportation, energy, economy have to build common networks to assist each other. Network interconnection in the energy sector is going forward slowly but it has to be continued. [1: 42-48]

Last but not least, another important subject is Roma integration within the V4 countries. "None of the countries facing this problem is able to handle it by itself in the future. It is necessary to initiate and find, within the entire EU, a way or a system of how to communicate with the other side, and how to put them in a position when they will be able to accept the offered assistance as cooperation" as the Slovak President Ivan Gašparovič emphasised in a V4 Summit in Karlovy Vary. ${ }^{9} \mathrm{He}$ also mentioned another future task, energy security, which has top priority within the Visegrad Cooperation and should be dealt with at a regional level in this area. Vaclav Claus, Czech president added that a new political dimension has opened before the V4 which makes it possible in the future for the V4 to formulate common interests and priorities, and maintained them at an international level.

8 The Nordic Council was founded in 1952 by Denmark, Sweden, Iceland, Norway, and Finland; its headquarters is in Copenhagen. www.norden.org/en/nordic-council/the-nordic-council (downloaded: 0104 2014)

9 V4 Presidents end their summit in Karlovy Vary. www.prezident.sk/?nahlad-foto\&gallery_ id=12086\&language $=$ en $($ downloaded: 0504 2014) 
A Further future area of cooperation can be environmental protection, and fostering eco- nomic growth. The V4 could be the main participant in the fostering of international democ- racy as it is a success story and an example to follow for the Balkans and the countries in the Eastern Partnership program. NATO and EU are going to provide the necessary tools for this task. [5]

Summarizing this topic I think there is an endless repository for future cooperation, which covers everything. There are some directions for cooperation which have already started, so these need to be broadened and deepened. If I wanted to organise the activities described above, the best would be the areas defined by the V4:

- cooperation within the V4 area;

- cooperation within the EU;

- cooperation with other partners;

- cooperation within NATO and other international organisations.

There is no more or less important area, each has a different dimension. However the most important task might be the coordination of work and the closer integration within the V4, the development the Visegrad identity, a support culture, education, infrastructure, and environmental protection.

A strong, influential regional organisation can be achieved within the framework of the EU, based on the voting rate; if we compare the vote of the V4 and the combined vote of France and Germany. So the V4 has a voice within the $\mathrm{EU}$ if all the four member states rep- resent a common position.

Common positions within NATO and other international organisations can also be ef- fective, based on the example of the EU. The Visegrad Cooperation is the centre of Central Europe, and it can be the leader of it, too in the future.

The cooperation of the V4 is a good example in the international scene because it can help other states to develop and protect democracy, joining international organisations through its experience.

\section{Conclusion}

In summary the Visegrad cooperation has to face many problems which are still waiting for a solution.

I outlined many difficulties of cooperation in my essay but these are often the opinion of sceptics. Yet I believe it was a good idea to collect them and analyse their views because I think negative criticism can be constructive and push forward cooperation. The lack of the tradition of good real regional cooperation is highlighted by me, because though there were earlier connections among the four countries, they were forced, not based on equal partner- ship, and also not represented by their own interests. Cooperation is important but in the meantime we should not forget about oursleves, we must act to advance our own interests, and all participants need to think of the cooperation positively. Therefore it is necessary to create unity among the Visegrad cooperation in which the Czech Republic, Hungary, Poland and Slovakia remain a separate entity; the motto could be: "unity in community".

These four countries have advanced very similarily from historical, political, economic, and cultural points of view, there are elements that connect and separate them. They often compete with each other, and have acted as the oppressor of the other party. The state of eco- 
nomic affairs greatly influences the success of cooperation, so they should seek to strengthen each other in this region, the single Visegrad cooperation can be a relevant player in Central Europe.

Last but not least, the sense of the Visegrad identity is highlighted by me because it would be very important if it were born. The four countries should be aware of all the citizens of Visegrad's spirituality to actually be able to work well in the organization.

Unfortunately there are lots of problems facing the Visegrad Cooperation since it was founded, but the lack of the tradition of a successful cooperation can be the most important in my opinion.

Many problems and hindering factors have been identified, some of them may have al- ready been solved, and others should be solved in the future. The barriers to collaboration can inspire the future tasks to be solved. Problems should be recognised, ranked (which I have not done) by the V4, and solutions need to be found.

A wide range of possible future cooperation were mentioned, lots of them are worthy of separate study and need further research. At the end I highlighted the issue of energy security because it has great importance, and I agree with the view that it cannot be solved alone by single states; a regional response must be given for which the cooperation of V4 offers the perfect possibility.

As for the final conclusion I shall return to my starting motto, quoted by Judit Hamberger: "now it is up to us at last, what is our present, and what will be our future". [1: 42]

\section{References}

[1] HAMBERGER J.: Közép-Európa politikai dimenziójának megvalósítási kísérlete: a visegrádi együttmúködés (V4). Külügyi Szemle 2010. nyár

[2] VISEGRAD GROUP: A visegrádi csoport története. www.visegradgroup.eu/tortenelem/ visegradi-csoport (downloaded: 0109 2012)

[3] CSICSAI M.: A Visegrádi Együttmüködés jelene és jövője. Kitekintő, 2012. 02. 27. www.kitekinto.hu/europa/2012/02/27/a_visegradi_egyuttmkodes_jelene_es_jovje/ (downloaded 0110 2012)

[4] DEICS N. (2005): Visegrádi együttmüködés a kibővült Európában - a V4-ek 15 éve. Budapest: Budapesti Gazdasági Föiskola, Külkereskedelmi Főiskolai Kar

[5] MCNALLY, C. (2010): New possibilities for the Visegrad Group. Washington, D.C.: CSIS www.csis.org/blog/new-possibilities-visegrad-group (downloaded: 0110 2012)

[6] NÁDAS N. (2011): A Visegrádi Csoport (V4) szerepének néhány kérdése a tagállamok EU csatlakozását követően, különös tekintettel a közös érdekképviseletre. Budapest: Budapesti Gazdasági Főiskola, Külkereskedelmi Föiskolai Kar

[7] VISEGRAD GROUP: Bratislava Declaration. www.visegradgroup.eu/2011/the-bratislava (downloaded: 0910 2012)

[8] VISEGRAD GROUP: Contents of Visegrad Cooperation 1999. www.visegradgroup.eu/ cooperation/contents-of-visegrad-110412 (downloaded: 2809 2012)

[9] NATIONAL INTELLIGENCE COUNCIL (2008): Global Trends 2025: A transformed word.www.dni.gov/nic/PDF_2025/2025_Global_Trends_Final_Report.pdf (downloaded: 07 04 2014) 
SZILÁGYI Ilona Mária: Problems and Future Possibilities of Visegrad Cooperation

[10] VISEGRAD GROUP: Guidelines on the Future Areas of Visegrad Cooperation. www.visegradgroup.eu/cooperation/guidelines-on-the-future-110412 (downloaded: 2809 2012)

[11] BAGÓ B. (2006): A visegrádi együttmüködés. Budapest: Budapesti Gazdasági Főiskola, Külkereskedelmi Föiskolai Kar

[12] VISEGRAD GROUP: Visegrad Declaration 2004. www.visegradgroup.eu/tortenelem/ visegradi-csoport (downloaded: 0210 2012) 